\title{
Sulindac increases the expression of APC mRNA in malignant colonic epithelial cells: an in vitro study
}

\author{
M Schnitzler, T Dwight, B G Robinson
}

\begin{abstract}
Background-Sulindac is a non-steroidal anti-inflammatory drug which induces regression of colonic polyps in patients with familial adenomatous polyposis. Animal and in vitro studies have shown that both the sulphide metabolite of sulindac, which is able to inhibit cyclo-oxygenase, and the sulphone metabolite, which lacks this ability, are able to inhibit the growth of colonic carcinoma cells. The exact mechanism by which these effects occurs is not known.
\end{abstract}

Aims-To examine the effect of sulindac sulphide and sulindac sulphone on the expression of APC messenger RNA (mRNA), and on the proliferation of colonic carcinoma cells in vitro.

Methods-The colonic carcinoma cell line LIM 1215 was treated with sulindac sulphide and sulindac sulphone $(10 \mu M$ or $100 \mu M)$ for 24 hours. Total RNA was extracted and APC mRNA was quantitated using competitive reverse transcription polymerase chain reaction. Measurements of cell number, cell proliferation, and prostaglandin $E_{2}$ concentrations were also made.

Results-A significant increase in APC mRNA was observed after treatment with $10 \mu \mathrm{M}$ of both sulindac sulphide and sulindac sulphone (control: 37.2 (19.7); $10 \mu \mathrm{M}$ sulindac sulphide: $129(112 \cdot 8) ; 10 \mu M$ sulindac sulphone: $207 \cdot 7(102 \cdot 9) \mathrm{pg} /(\mathrm{g}$ total RNA) $(p<0 \cdot 05)$. Prostaglandin $E_{2}$ concentrations were significantly reduced after treatment with sulindac sulphide, but not after sulindac sulphone. Both agents produced a dose dependent reduction in cell numbers and cell proliferation, which was more noticeable after treatment with sulindac sulphide.

Conclusions-Both sulindac sulphide and sulindac sulphone inhibit the growth of carcinoma cells in vitro and cause an increase in APC mRNA. The effect of these agents on colonic carcinogenesis is not mediated entirely by means of an inhibition of prostaglandin biosynthesis. (Gut 1996; 38: 707-713)

Keywords: APC gene, sulindac, gene expression, colonic carcinoma, familial polyposis syndrome.

Dr B G Robinson, Molecular Genetics Unit, Kolling Institute of Medical

Research, Royal North Shore Hospital and University of Hospital and University of 2065, Australia.

Accepted for publication

20 November 1995 Sulindac (cis-5-fluoro-2-methyl-1-[p-(methylsulphinyl) benzylidene] indene-3-acetic acid) is a non-steroidal anti-inflammatory (NSAID) drug which had primarily been used in the treatment of rheumatic diseases. It acts as a competitive inhibitor of cyclo-oxygenase, a key enzyme in the prostaglandin biosynthetic pathway. ${ }^{1}$

In 1983 Waddell and Loughry first reported that sulindac induced the regression of rectal polyps in patients with familial adenomatous polyposis (FAP) who had undergone subtotal colectomy and ileorectal anastomosis. ${ }^{2}$ This initial finding has subsequently been confirmed by several other investigators who have shown that sulindac causes a reduction in the number and size of polyps in patients with FAP, both in the intact colon and in the rectum after colectomy. ${ }^{3-6}$ Sulindac is ingested orally as an inactive prodrug. It is reduced to its active form, sulindac sulphide, by the action of colonic bacteria resulting in high levels of the active agent in the colon. ${ }^{7}$ The observed effect of sulindac on polyp growth is reversible: recurrence is observed on stopping treatment.

Despite its efficacy in inducing polyp regression, the role of sulindac in reducing the risk of colorectal carcinoma is not yet established. There have been reports of the development of rectal cancer in patients being treated with this agent, despite regular endoscopic surveillance.$^{89}$ In one study, reduced prostaglandin biosynthesis was observed in colonic mucosal biopsy specimens from FAP patients on sulindac therapy. ${ }^{6}$ Despite this observation, the mechanism by which sulindac inhibits the development of polyps in FAP remains unclear. Similar inhibition of polyp development has not been seen with other NSAIDs such as indomethacin, ${ }^{10}$ and studies of nonFAP patients with colonic polyps have also failed to show a reduction in polyp number or size after sulindac treatment, although only small numbers of patients have been studied. ${ }^{11} 12$ Evidence that the observed effect of sulindac may be mediated via a prostaglandin-independent mechanism is provided by studies which have shown a lack of correlation between a reduction in colonic prostaglandin biosynthesis and the inhibition of carcinogen induced colonic tumours. ${ }^{1314}$ In addition, sulindac sulphone, a metabolite of sulindac which lacks the cyclo-oxygenase inhibitory activity of the active form of the drug, has been shown to have a similar effect to that of the active form of the drug, sulindac sulphide, both in vitro and in a rat model of colonic carcinogenesis. ${ }^{15} 16$

In view of the apparent specificity of sulinleast some of its effect is mediated via a 
prostaglandin-independent mechanism, we have examined the effect of sulindac sulphide and sulindac sulphone on APC mRNA in cultured colonic cells.

The APC gene is a tumour suppressor gene which is mutated in the germline of patients with FAP, and also in a significant number of sporadic colonic neoplasms. ${ }^{17} 18$ In the vast majority of cases, the mutation is inactivating, and results in the formation of a truncated mutant protein. The APC protein is thought to have a role in cell adhesion, as the wildtype product has been shown to associate with the cell adhesion proteins $\beta$-catenin and E-cadherin, and is able to regulate intracellular levels of $\beta$-catenin. ${ }^{1921} \mathrm{~A}$ possible role in cell division has been suggested in view of the cytoskeleton, a function which is lost by mutant forms of the protein. ${ }^{22} 23$ APC mRNA is ubiquitously expressed, ${ }^{24} 25$ but levels of expression in adult human tissues are low, and the factors which regulate its expression have not been characterised. We have developed a quantitative reverse transcription polymerase chain reaction (QRTPCR) based method for the measurement of APC mRNA, and have used this to quantitate APC mRNA in colonic cells after treatment with sulindac.

\section{Methods}

CELL CULTURE AND SULINDAC TREATMENT

The colonic carcinoma cell line LIM 1215 was used. ${ }^{26}$ Cells were maintained in Dulbecco's modified Eagle's medium (DMEM), supplemented with $10 \%$ fetal calf serum at $37^{\circ} \mathrm{C}$, with $5 \% \mathrm{CO}_{2}$.

Cells were grown to $75 \%$ confluence in $75 \mathrm{~cm}^{2}$ flasks (Corning, New York, USA) and were treated in serum free medium for 24 hours. Quintuplicate flasks were treated with $10 \mu \mathrm{M}$ or $100 \mu \mathrm{M}$ sulindac sulphide or sulindac sulphone in dimethyl sulphoxide (DMSO) or with vehicle alone. After treatment, the cells were washed with phosphate buffered saline, trypsinised, harvested, and snap frozen on dry ice.

\section{RNA EXTRACTION}

Cell pellets were sonicated and total cytoplasmic RNA was extracted using the guanidinium thiocyanate method. ${ }^{27}$ The RNA was quantitated by spectrophotometric analysis and electrophoresed in $1.4 \%$ agarose gels to assess its quality.

QRTPCR

This was performed with the use of an internal synthetic RNA standard. A 266 base pair fragment of the APC gene corresponding to bases 690 to 965 of the cDNA was generated by PCR using the primers $5^{\prime}$ AGAATTCAGCAAATCGAAAGG $3^{\prime}$ and $5^{\prime}$ CTTGGTTCCCAGATGACTG $3^{\prime}$, and subcloned into the plasmid vector pGEMT (Promega Corp, Madison, WI, USA). A 33 base pair fragment was removed from this construct by DdeI digestion, and the plasmid was linearised by HinfI digestion (New England Biolabs, Beverley, Massachusetts, USA) and purified by phenol-chloroform extraction and ethanol precipitation. Synthetic RNA was transcribed using SP6 polymerase (Boehringer Mannheim GmbH, Germany), treated with DNase I (Gibco BRL, Gaithersburg, MA) for 60 minutes, and purified by phenol-chloroform extraction and ethanol precipitation.

Oligonucleotide primers were designed and synthesised to amplify a 251 base pair fragment of the human APC gene and a 218 base pair fragment from synthetic RNA. (Forward primer as above and reverse primer $5^{\prime}$ CTTCGAGGTGCAGAGTGTGT 3').

Reverse transcription of RNA was carried out in a final volume of $30 \mu \mathrm{l}$ containing 10 mmol Tris $\mathrm{HCl}, 50 \mathrm{mmol} \mathrm{KCl}, 2 \cdot 5 \mathrm{mmol}$ $\mathrm{MgCl}, 0.1 \mathrm{mmol}$ of dATP, dCTP, dGTP and dTTP, $0.7 \mu \mathrm{mol}$ reverse primer, $0.5 \mathrm{U}$ RNAsin (Promega Corp), $30 \mathrm{mmol}$ DTT, 40 U Superscript reverse transcriptase (Gibco BRL), varying dilutions of synthetic RNA, and a constant known quantity of total RNA. The reaction was performed at $49^{\circ} \mathrm{C}$ for 15 minutes and the reverse transcriptase was inactivated by heating to $95^{\circ} \mathrm{C}$ for five minutes followed by immediate quenching on ice. Amplification of the resulting cDNA samples was performed in a final volume of $50 \mu$ by the addition of $10 \mathrm{mmol}$ Tris $\mathrm{HCl}, 50 \mathrm{mmol} \mathrm{KCl}, 0.35 \mu \mathrm{mol}$ forward primer, $5 \mu \mathrm{Ci}{ }^{33} \mathrm{P} \alpha \mathrm{dATP}$ (Amersham International plc, Buckinghamshire) and 0.5 U Taq polymerase (Perkin Elmer/Cetus, Norwalk, CT, USA). Thirty six cycles of denaturation at $94^{\circ} \mathrm{C}$ for one minute, annealing at $63^{\circ} \mathrm{C}$ for 30 seconds, and extension at $72^{\circ} \mathrm{C}$ for 30 seconds were performed using a Perkin Elmer/Cetus 9600 thermal cycler. Negative controls consisting of reactions from which reverse transcriptase had been omitted and reactions to which no RNA had been added were performed for both endogenous RNA and synthetic RNA samples in all cases. Reaction products were separated on $10 \%$ acrylamide gels, which enabled resolution of the synthetic RNA derived product of $218 \mathrm{bp}$, and the endogenous mRNA-derived product of $251 \mathrm{bp}$ (Fig 1). The relative amounts of the two products were quantitated using a Phosphorimager (Molecular Dynamics, USA). Competition equivalence points were determined by interpolation on graphs of the logarithm of the ratio of synthetic RNA derived product to endogenous RNA derived product plotted against the logarithm of the copy number of competitive template.

QRTPCR analysis was carried out at least twice for each sample and a mean value obtained for the number of molecules of APC mRNA per $\mu g$ of total RNA. Statistical analysis was performed by means of the Student's t-test using an unpaired two-tailed analysis of logarithmically transformed data.

PROSTAGLANDIN $\mathrm{E}_{2}$ MEASUREMENTS

Prostaglandin $\mathrm{E}_{2}\left(\mathrm{PGE}_{2}\right)$ levels were measured 
in the medium of treated and control cells. Aliquots of $200 \mu \mathrm{l}$ of medium were removed from each flask after 24 hours and stored at $-70^{\circ} \mathrm{C}$ until processed. All samples were analysed within two weeks of collection. $\mathrm{PGE}_{2}$ was measured by radioimmunoassay using a Prostaglandin $\mathrm{E}_{2}$ [ $\left.{ }^{125} \mathrm{I}\right]$ RIA kit which utilises an iodinated $\mathrm{PGE}_{2}$ analogue as a tracer and a specific rabbit anti-PGE 2 antibody (Du Pont NEN, Boston, MA, USA).

\section{CELL PROLIFERATION}

Cell proliferation was measured by using a tritiated thymidine assay. Two $\times 10^{5}$ cells were plated into 24 well plates (Corning) and allowed to grow for 24 hours. Cells in triplicate wells were treated with sulindac sulphide or sulphone $10 \mu \mathrm{M}, 50 \mu \mathrm{M}$, and $100 \mu \mathrm{M}$ or with vehicle alone for 24 hours. A further three wells were exposed to $70 \%$ ethanol for 30 minutes, and then washed with PBS, to act as a negative control. All wells were then treated with $1 \mathrm{ml}$ medium containing $2 \mathrm{mCi}\left[{ }^{3} \mathrm{H}\right]$ thymidine (ICN Biomedicals, Costa Mesa, CA, USA) and incubated at $37^{\circ} \mathrm{C}$ for four hours. Incorporation was measured in a $\beta$ counter (Packard Instrumental Company, Meriden, Connecticut, USA), and expressed as counts per minute (cpm).

\section{CELL COUNTS}

Two $\times 10^{5}$ LIM 1215 cells were plated into 24 well plates (Corning) and allowed to grow for 24 hours. Cells in triplicate wells were treated with sulindac sulphide or sulphone $10 \mu \mathrm{M}$, $50 \mu \mathrm{M}$, and $100 \mu \mathrm{M}$ or with vehicle alone for 24 hours. The cells were then trypsinised, pelleted, and resuspended in an equal volume of medium and Trypan blue dye (Sigma Chemical Co, Irvine, UK). The cells were counted and the results expressed as the number of viable cells per well.

\section{Results}

QUANTITATION OF APC MRNA

Treatment with both sulindac sulphide and sulindac sulphone resulted in an increase in APC mRNA levels when compared with

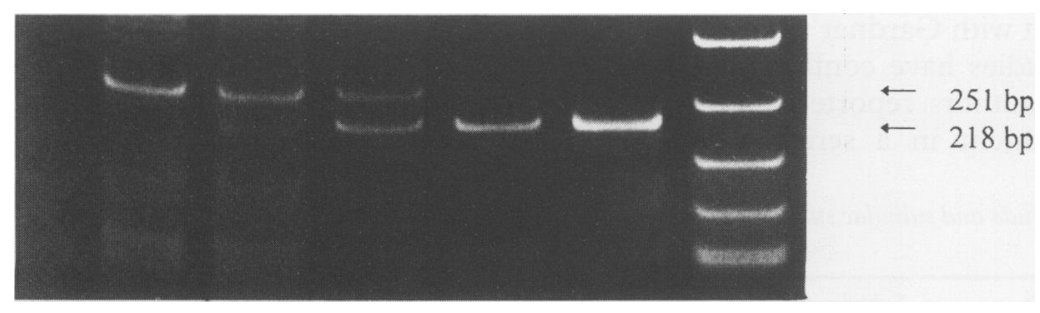

$$
\begin{array}{llllll}
1 & 2 & 3 & 4 & 5 & 6
\end{array}
$$

Figure 1: Ethidium bromide stained acrylamide gel showing amplification of endogenous $R N A$ derived from normal duodenum $(251 \mathrm{bp})$ with varying quantities of synthetic $R N A$ (218 bp). Lane 1: total RNA $1 \mu \mathrm{g}$. Lane 2: total $R N A 1 \mu \mathrm{g}$ with synthetic $R B A 2 \times 10^{5}$

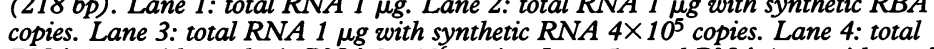
$R N A 1 \mu g$ with synthetic $R N A 2 \times 10^{6}$ copies. Lane 5: total RNA $1 \mu \mathrm{g}$ with synthetic $R N A 4 \times 10^{6}$ copies. Lane 6: marker.

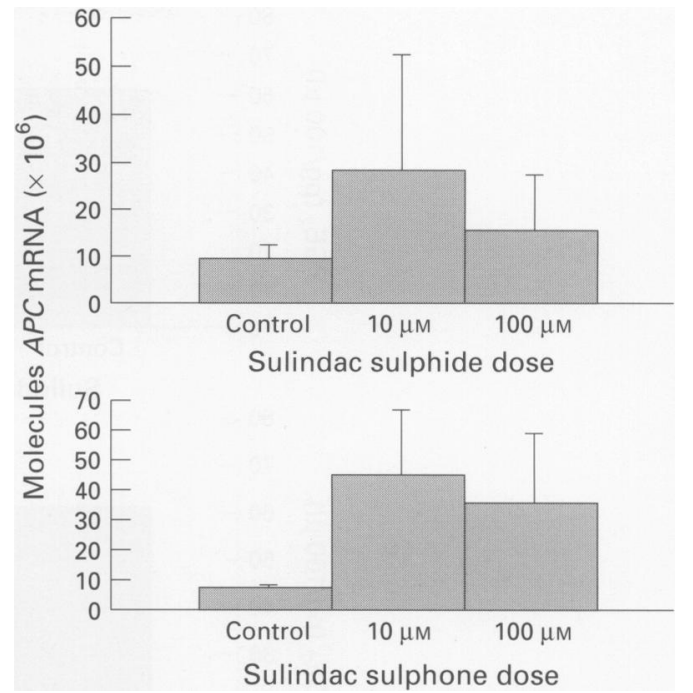

Figure 2: The effect of sulindac sulphide and sulindac sulphone on APC MRNA in LIM 1215 cells.

controls. This effect was observed after treatment with $10 \mu \mathrm{M}$ of each agent, and treatment with the $100 \mu \mathrm{M}$ dose produced a smaller increase in APC mRNA. In cells treated with sulindac sulphide, the mean quantity of APC mRNA in control cells was $8 \times 10^{6}$ molecules per $\mu \mathrm{g}$ total RNA, while in cells treated with $10 \mu \mathrm{m}$ and $100 \mu \mathrm{M}$ sulindac sulphone this was increased to $2.8 \times 10^{7}$ and $1.5 \times 10^{7}$ molecules per $\mu \mathrm{g}$ total RNA respectively $(p=0.05$ and $\mathrm{p}=0 \cdot 7)$. In cells treated with sulindac sulphone, the mean quantity of APC mRNA in control cells was $92 \times 10^{6}$ molecules per $\mu \mathrm{g}$ total RNA, while in cells treated with $10 \mu \mathrm{M}$ and $100 \mu \mathrm{M}$ sulindac sulphone this was increased to $4.5 \times 10^{7}$ and $3.6 \times 10^{7}$ molecules per $\mu$ g total RNA respectively $(p=0.017$ and $\mathrm{p}=0 \cdot 11$ ) (Fig 2).

\section{PGE $_{2}$ MEASUREMENTS}

The mean value for $\mathrm{PGE}_{2}$, in culture medium for control cells was $63(10 \cdot 4) \mathrm{pg} / 100 \mu \mathrm{l}$. Treatment with sulindac sulphide at doses of both $10 \mu \mathrm{M}$ and $100 \mu \mathrm{M}$ caused a significant reduction in $\mathrm{PGE}_{2}$ values in the culture medium $(6.0(2.5) \mathrm{pg} / \mathrm{ml}$ and $21.7(5.2) \mathrm{pg} / \mathrm{ml}$ respectively $\mathrm{p}<0.05)$. Treatment with sulindac sulphone at the same doses did not produce any statistically significant reduction in $\mathrm{PGE}_{2}$ levels (Fig 3).

\section{CELL PROLIFERATION}

Cell proliferation, as measured by tritiated thymidine incorporation, was significantly

Table 1 Effect of sulindac sulphide and sulindac sulphone on cell proliferation

\begin{tabular}{lcc}
\hline & Sulindac sulphide (cpm) & Sulindac sulphone (cpm) \\
\hline Control & $41330(5136)$ & $37404(12175)$ \\
$10 \mu \mathrm{M}$ & $41167(5649)$ & $30868(1698)$ \\
& $\mathrm{p}=0.88$ & $\mathrm{p}=0.51$ \\
$50 \mu \mathrm{M}$ & $2869(791)$ & $23443(7865)$ \\
$100 \mu \mathrm{M}$ & $\mathrm{p}=0.025$ & $\mathrm{p}=0.13$ \\
& $\mathrm{p}=0.0253$ & $7873(1564)$ \\
& $\mathrm{p}=0.05$ \\
\hline
\end{tabular}

$\mathrm{p}$ Values for Kruskal-Wallis $\chi^{2}$ analysis compared with control. 

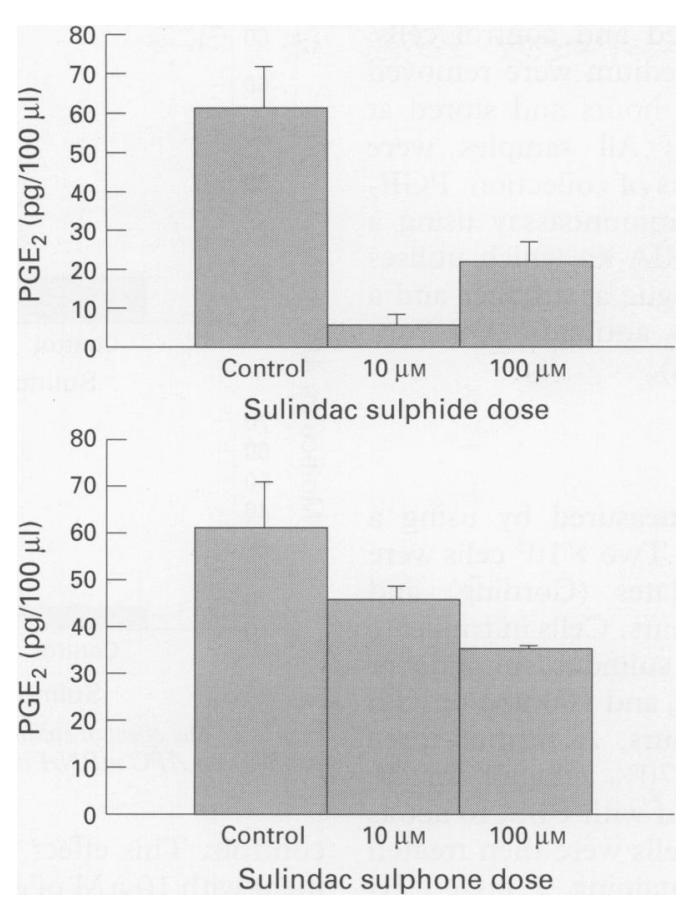

Figure 3: The effect of sulindac sulphide and sulindac sulphone on prostaglandin $E_{2}\left(P G E_{2}\right)$ concentrations in LIM 1215 cells.

reduced after treatment with both sulindac sulphide and sulindac sulphone at the $100 \mu \mathrm{M}$ dose, and by treatment with $50 \mu \mathrm{M}$ sulindac sulphide. The values obtained, expressed as mean (SD) $\mathrm{cpm}$ are shown in Table I and Figure 4.

\section{CELL COUNTS}

A dose dependent reduction in cell counts was observed after treatment with both sulindac sulphide and sulphone. The results are shown in Table II and Figure 5. There was a statistically significant reduction in the number of cells after treatment with each agent at the $50 \mu \mathrm{M}$ and $100 \mu \mathrm{M}$ doses, but not at the $10 \mu \mathrm{M}$ dose. The reduction in cell counts was slightly greater in the sulindac sulphide treated cells than in the sulindac sulphone treated cells, but this difference was not statistically significant.

\section{Discussion}

Since the observation of Waddell and Loughry in 1983 that sulindac inhibited the growth of colonic polyps in a patient with Gardner's syndrome, ${ }^{2}$ several other studies have confirmed this finding. The same authors reported the results of sulindac treatment in a series of

Table 2 Effect of sulindac sulphide and sulindac sulphone on cell counts

\begin{tabular}{lll}
\hline & $\begin{array}{l}\text { Sulindac sulphide } \\
\left(10^{6} \text { cells per } m l\right)\end{array}$ & $\begin{array}{l}\text { Sulindac sulphone } \\
\left(10^{6} \text { cells per ml }\right)\end{array}$ \\
\hline Control & $3(0.5)$ & $3(0.5)$ \\
$10 \mu \mathrm{M}$ & $2 \cdot 5(0.88)$ & $2 \cdot 6(0.76)$ \\
$50 \mu \mathrm{M}$ & $\mathrm{p}=0.44$ & $\mathrm{p}=0.51$ \\
& $0.8(0.36)$ & $1.5(0.36)$ \\
$100 \mu \mathrm{M}$ & $0.63(0.04)$ & $\mathrm{p}=0.05$ \\
& $\mathrm{p}=0.046$ & $1.5(0.71)$ \\
& & $\mathrm{p}=0.05$ \\
\hline
\end{tabular}

$\mathrm{p}$ Values for Kruskal-Wallis $\chi^{2}$ analysis compared with control. seven patients with FAP, of whom three had undergone previous colectomy and ileo-rectal anastomosis while the remainder had intact colons. In each case there was total or neartotal elimination of polyps, including two patients who had more than one thousand polyps. ${ }^{10}$ It is of interest that one patient had previously been treated with indomethacin, another NSAID with cyclo-oxygenase inhibitory activity, without any demonstrable effect on her colonic polyps. Polyp regression was maintained in all patients while on sulindac, and during a mean follow up period of $4 \cdot 6$ years there was no development of malignancy.

Rigau et al reported similar findings in a study of seven patients with diffuse colonic polyposis, all of whom experienced a marked reduction in polyp size and number after six months' treatment with sulindac $(200 \mathrm{mg}$ orally twice daily). ${ }^{6}$ In four of these patients, $\mathrm{PGE}_{2}$ and 6-keto-PGF ${ }_{1 \alpha}$-levels in the colonic mucosa were measured by radioimmunoassay. In every case there was a significant reduction in the level of each of these prostaglandins in both apparently normal colonic mucosa and in polyp tissue after six months of treatment with sulindac. These results have been confirmed subsequently by randomised, placebo controlled, double blind studies. ${ }^{346}$ The effect of sulindac treatment on duodenal polyps has also been examined, but is less marked than that observed in the colon, with some effect on small polyps, but no significant effect on polyps larger than $2 \mathrm{~mm} .{ }^{528}$

It has been shown that the NSAID indomethacin, when administered in a dose known to suppress the development of 1,2dimethylhydrazine colonic tumours in rats, ${ }^{29}$ does not produce a reduction in endogenous colonic prostaglandin synthesis, ${ }^{14}$ suggesting that the growth inhibitory effects of NSAIDs are not mediated entirely via their antiprostaglandin activity. Administration of a $\mathrm{PGE}_{2}$ analogue also failed to reverse the suppressive effect of indomethacin on colonic

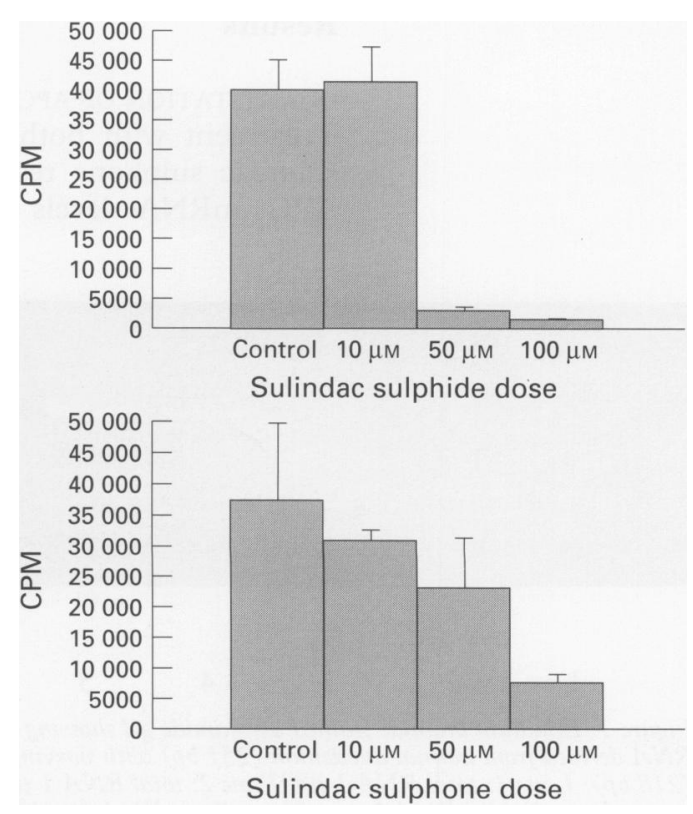

Figure 4: The effect of sulindac sulphide and sulindac sulphone on cell proliferation. 


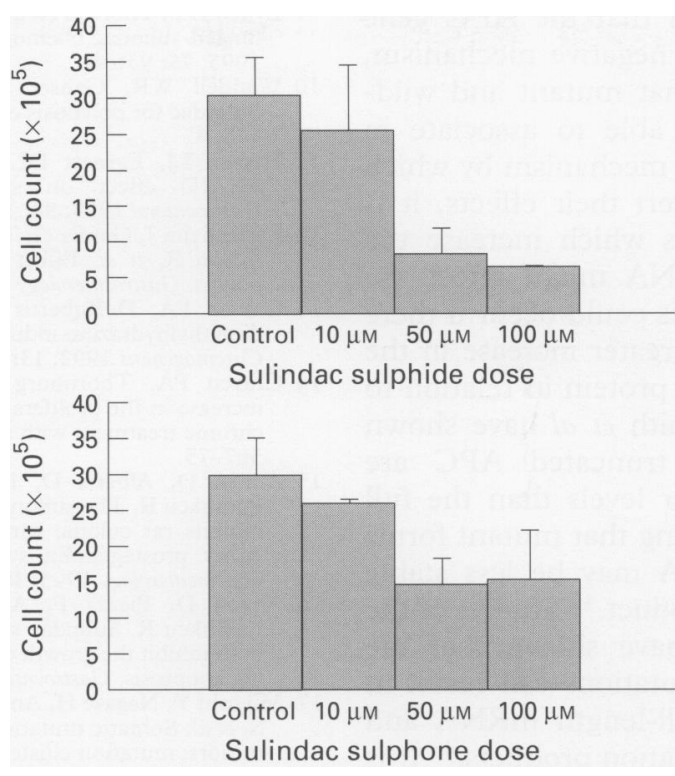

Figure 5: The effect of sulindac sulphide and sulindac sulphone on cell numbers.

tumour formation in a rat. ${ }^{30}$ Conversely, Craven and DeRubertis administered aspirin to rats in doses sufficient to suppress colonic $\mathrm{PGE}_{2}$ production by $95 \%$, without observing a reduction in 1,2-DMH-induced colonic carcinoma in a rat model. ${ }^{13}$

The effect of sulindac on cell proliferation has been assessed in several clinical studies. Labayle et al measured Ki67 indices in six patients who had a significant reduction in polyp numbers while being treated with sulindac, and failed to detect any difference in the measurement of cell cycling. ${ }^{4}$ Nugent et al, in a controlled trial of 24 patients with rectal polyps following ileorectal anastomosis, showed a significant reduction in polyp size and number, which was accompanied by a reduction in epithelial proliferation as measured by incorporation of 5-bromo-2' -deoxyuridine. ${ }^{5}$ Others have shown a reduction in colonic cell proliferation in vitro in response to sulindac treatment. $^{31}$ Of note, a similar reduction in cell proliferation was also observed after treatment with sulindac sulphone, suggesting that this effect occurs independently of the prostaglandin biosynthetic pathway.

The ability of colonic mucosa to synthesise various prostaglandins has been demonstrated in a number of studies. ${ }^{32} 33$ Higher levels of prostaglandins, particularly $\mathrm{PGE}_{2}$, have been measured in colonic tumours than in surrounding normal mucosa. ${ }^{32} 34$ Cell lines derived from human colonic tumours do not always produce detectable quantities of prostaglandins, ${ }^{35}$ however, the cell line used in this study, LIM 1215, produced sufficient $\mathrm{PGE}_{2}$ to be detected by radioimmunoassay, and we showed a significant reduction in $\mathrm{PGE}_{2}$ levels after treatment with sulindac sulphide. The metabolite sulindac sulphone failed to suppress $\mathrm{PGE}_{2}$ levels in this cell line, confirming the fact that it lacks cyclo-oxygenase inhibitory activity. Despite this lack of effect on prostaglandin production, sulindac sulphone had a similar effect to that of the active form of the drug in increasing APC mRNA levels.
Sulindac sulphide has been shown to inhibit the expression of several intermediate early genes, including c-myc, c-fos, and jun-B, whose expression was induced by $\mathrm{TGF} \alpha$ stimulation in a rat model. ${ }^{36}$ Both indomethacin and sulindac sulphide inhibited the expression of the rat homologue of the cyclo-oxygenase- 2 (COX-2) gene, and they have also been shown to reduce prostaglandin production in this model. ${ }^{37}$ Despite these observations, the effect on the expression of the intermediate early genes was seen only with sulindac sulphide, and was not observed after treatment with indomethacin. Nuclear run-on assays showed that the inhibition occurred at the level of transcription, and suggested that sulindac sulphide has a direct effect on the expression of these genes.

Several other mechanisms by which sulindac could have its effect have been proposed, including the suppression of ornithine decarboxylase activity, alteration of cell cycle kinetics, and induction of apoptosis. ${ }^{163839} \mathrm{~A}$ recent small clinical study has suggested that sulindac is able to induce apoptosis in the rectal epithelium of FAP patients, and in vitro evidence supports a role for both the sulphide and sulphone forms of this drug in causing apoptosis in colonic carcinoma cell lines. ${ }^{4041}$

Both sulindac sulphide and sulindac sulphone are able to cause a reduction in cell numbers and cell proliferation in cultured colonic cells. ${ }^{31} 38$ In three colonic carcinoma cell lines, the $50 \%$ inhibitory concentration for the sulphide form ranged from 35 to $80 \mu \mathrm{M}$, while for the sulphone derivative, the range was 49 to $119 \mu M$. Similar results were observed in the LIM 1215 cell line examined in this study. A reduction in cell numbers and cell proliferation occurred after treatment with both agents at doses of 50 and $100 \mu \mathrm{M}$, with the effect of sulindac sulphide being more marked than for sulindac sulphone. Treatment with each agent at the $10 \mu \mathrm{M}$ concentration did not result in a significant reduction in cell number or proliferation.

In summary, this study has confirmed reports that both the sulphide and sulphone metabolites of sulindac are able to inhibit the growth of colonic cells in culture, and has also demonstrated that this effect is not dependent upon a reduction in $\mathrm{PGE}_{2}$ synthesis. In addition, it has been shown that both agents are able to increase the expression of APC mRNA as measured by QRT PCR. The finding that these drugs have an effect on APC mRNA is consistent with the evidence from clinical studies of an apparently specific effect of sulindac on polyps in FAP patients when compared to sporadic polyps in non-FAP patients. ${ }^{11} 12$ In individuals with FAP, the inactivating germline mutation causes a reduction in the amount of wild-type APC protein produced, which might possibly be below a threshold necessary to prevent neoplasia. ${ }^{42}$ One possible explanation suggested by these results is that an increase in the expression of APC mRNA induced by sulindac could increase the amount of normal gene product above the threshold required to maintain growth control. 
It has been suggested that the APC gene may act via a dominant negative mechanism, in view of the finding that mutant and wildtype APC proteins are able to associate in vivo. ${ }^{43}$ Even if this is the mechanism by which APC gene mutations exert their effects, it is still possible that factors which increase the expression of APC mRNA might affect the function of the gene. This could occur if there were a proportionately greater increase in the quantity of normal APC protein in relation to the mutant product. Smith et al have shown that certain forms of truncated APC are expressed at much lower levels than the full length products, suggesting that mutant forms of the protein or mRNA may be less stable than the normal gene product. ${ }^{44}$ Studies of the human $\beta$-globin gene have shown that the presence of nonsense mutations can result in destabilisation of the full-length mRNA and the production of degradation products. ${ }^{45}$ It is thus possible that the increase in APC mRNA produced in response to sulindac treatment could result in a relative increase in the quantity of the normal APC protein as compared to the abnormal gene product. We speculate that this may in turn reduce the proportion of the full length APC sequestered by the mutant protein and restore some of the tumour suppressing function of the gene.

Sulindac sulphide and sulindac sulphone are able to inhibit the growth of colonic cells both in vitro and in animal models. The sulphide form of the drug has also been shown to be effective in causing regression of polyps in patients with FAP. Several different mechanisms have been proposed to account for the action of these agents in preventing colonic neoplasia, including the inhibition of cyclooxygenase activity, alteration of cell cycle kinetics, the inhibition of intermediate early gene expression, and the induction of apoptosis. The present study suggests that another possible mode of action is related to an increase in colonic APC mRNA. It is likely that a combination of these different mechanisms, some of which may be inter-related, will ultimately be shown to mediate the effects of sulindac on the colonic epithelium.

1 Duggan DE, Hooke KF, Risley EA, Shen TY, Arman CG. Identification of the biologically active form of sulindac. f Pharmacol Exp Ther 1977; 201: 8-13.

2 Waddell WR, Loughry RW. Sulindac for polyposis of the colon. F Surg Oncol 1983; 24: 83-7.

3 Giardiello FM, Hamilton SR, Krush AJ, Piantadosi S Hylind LM, Celano P, et al. Treatment of colonic and rectal adenomas with sulindac in familial adenomatous polyposis. N Engl f Med 1993; 328: 1313-6.

4 Labayle D, Fischer D, Vielh P, Drouhin F, Pariente A Bories C, et al. Sulindac causes regression of rectal polyps in familial adenomatous polyposis. Gastroenterology 1991; in familial aden $635-9$.

5 Nugent KP, Farmer KC, Spigelman AD, Williams CB, Phillips RK. Randomized controlled trial of the effect of sulindac on duodenal and rectal polyposis and cell proliferation in patients with familial adenomatous polyposis Br F Surg 1993; 80: 1618-9.

6 Rigau J, Pique JM, Rubio E, Planas R, Tarrech JM, Bordas JM. Effects of long-term sulindac therapy on colonic polyposis. Ann Intern Med 1991; 115: 952-4

7 Hucker HB, Stauffer SC, White SD, Rhodes RE, Arison BH, Umbenhauer ER, et al. Physiologic disposition and metabolic fate of a new anti-inflammatory agent, cis-5-fluro-2-methyl-1-(p-(methylsulfinyl)-benzylidenyl)cis-5-fluro-2-methyl-1-(p-(methylsulfinyl)-benzylidenyl)man. Drug Metab Dispos 1973; 1: 721-36.

8 Niv Y, Fraser GM. Adenocarcinoma in the rectal segment in familial polyposis coli is not prevented by sulindac in familial polyposis coli is not prevented
9 Lynch HT, Thorson AG, Smyrk T. Rectal cancer after prolonged sulindac chemoprevention. A case report. Cancer 1995; 75: 936-8.

10 Waddell WR, Ganser GF, Cerise EJ, Loughry RW. Sulindac for polyposis of the colon. Am F Surg 1989; 157: 175-9.

11 Hixson LJ, Earnest DL, Fennerty MB, Sampliner RE. NSAID effect on sporadic colon polyps. $A m \mathcal{J}$ Gastroenterol 1993; 88: 1652-6.

12 Ladenheim J, Garcia G, Titzer D, Herzerberg H, Lavori P Edson R, et al. Effect of sulindac on sporadic colonic Edson R, et al. Effect of sulindac on spora
polyps. Gastroenterology 1995; 108: 1083-7.

13 Craven PA, DeRubertis FR. Effects of aspirin on 1,2dimethylhydrazine-induced colonic carcinogenesis. Carcinogenesis 1992; 13: 541-6.

14 Craven PA, Thornburg K, DeRubertis FR. Sustained increase in the proliferation of rat colonic mucosa during chronic treatment with aspirin. Gastroenterology 1988; 94 567-75.

15 Ahnen D, Alberts D, Hixson L, Paranka N, Burt $R$ Pamukcu R. The sulfone metabolite of sulindac (FGN-1) inhibits rat colonic carcinogenesis but does not inhibit either prostaglandin synthesis of colonic proliferation. Gastroenterology 1995; 108: A444.

16 Ahnen D, Piazza F, Alberts D, Paranka N, Burt R, Pamukcu R. Sulindac sulfide (SS) and sulfone (FGN-1) both inhibit the growth of colon cancer cell lines by inducing apoptosis. Gastroenterology 1995; 108: A443

17 Miyoshi Y, Nagase H, Ando H, Horii A, Ichii S, Nakatsuru $S$, et al. Somatic mutations of the APC gene in colorectal tumors: mutation cluster region in the APC gene. Human Molecular Genetics 1992; 1: 229-33.

18 Nagase H, Nakamura Y. Mutations of the APC (adenomatous polyposis coli) gene. Human Mutation 1993; 2: tous polyp

19 Rubinfeld B, Souza B, Albert I, Muller O, Chamberlain SH, Masiarz FR, et al. Association of the APC gene product with beta-catenin. Science 1993; 262: 1731-4.

20 Su LK, Vogelstein B, Kinzler KW. Association of the APC tumor suppressor protein with catenins. Science 1993; 262: $1734-7$

21 Munemitsu S, Albert I, Souza B, Rubinfeld B, Polakis PX. Regulation of intracellular beta-catenin levels by the adenomatous polyposis coli (APC) tumor-suppressor protein. Proc Natl Acad Sci USA 1995; 92: 3046-50.

22 Munemitsu S, Souza B, Muller O, Albert I, Rubinfeld B, Polakis P. The APC gene product associates with microtubules in vivo and promotes their assembly in vitro. tubules in vivo and promotes
Cancer Res $1994 ; 54: 3676-81$.

23 Smith KJ, Levy DB, Maupin P, Pollard TD, Vogelstein B, Kinzler KW. Wild-type but not mutant APC associates with the microtubule cytoskeleton. Cancer Res 1994; 54: 3672-5.

24 Groden J, Thliveris A, Samowitz W, Carlson M, Gelbert L, Albertsen $\mathrm{H}$, et al. Identification and characterization of the familial adenomatous polyposis coli gene. Cell 1991, 66: 589-600.

25 Kinzler KW, Nilbert MC, Su LK, Vogelstein B, Bryan TM, Levy DB, et al. Identification of FAP locus genes from chromosome 5q21. Science 1991; 253: 661-5.

26 Whitehead RH, Macrae FA, St John DJ, Ma J. A colon cancer cell line (LIM1215) derived from a patient with inherited nonpolyposis colorectal cancer. $\mathcal{f}$ Natl Cancer inst 1985; 74: 759-65.

27 Chomczynski P, Sacchi N. Single-step method of RNA isolation by acid guanidinium thiocyanate-phenol-chloroform extraction. Anal Biochem 1987; 162: 156-9.

28 Debinski HS, Trojan J, Nugent KP, Spigelman AD, Phillips RKS. Effect of sulindac on small polyps in familial adenomatous polyposis. Lancet 1995; 345: 855-6.

29 Pollard M, Luckert PH. Effect of indomethacin on intestinal tumors induced in rats by the acetate derivative of dimethylnitrosamine. Science 1981; 214: 558-9.

30 Narisawa T, Hermanek P, Habs M, Schmahl D. Reduction of carcinogenicity of $\mathrm{N}$-nitrosomethylurea by indomethacin and failure of resuming effect of prostaglandin methacin and failure of resuming effect of prostaglandin $\mathrm{E} 2\left(\mathrm{PGE}_{2}\right)$ against ind
1984; 108: 239-42.

31 Hixson LJ, Alberts DS, Krutzsch M, Einsphar J, Brendel K, Gross PH, et al. Antiproliferative effect of nonsteroidal antiinflammatory drugs against human colon cancer cells. Cancer Epidemiology, Biomarkers and Prevention 1994; 3 433-8.

32 Bennett A, Tacca MD, Stamford IF, Zebro T. Prostaglandins from tumours of human large bowel. Br $\mathcal{F}$ Cancer 1977; 35: 881-4.

33 Knapp HR, Oelz O, Sweetman BJ, Oates JA. Synthesis and metabolism of prostaglandins $\mathrm{E}_{2}, \mathrm{~F}_{2}$ alpha and $\mathrm{D}_{2}$ by the metabolism of prostaglandins $E_{2}, F_{2}$ alpha and $D_{2}$ by the rat gastrointestinal tract. Stimulation by a hypertonit

34 Pugh S, Thomas GA. Patients with adenomatous polyps and carcinomas have increased colonic mucosal prostaglandin $\mathrm{E}_{2}$. Gut 1994; 35: 675-8.

35 Hubbard WC, Alley MC, McLemore TL, Boyd MR Profiles of prostaglandin biosynthesis in sixteen established cell lines derived from human lung, colon, prostate, and ovarian tumors. Cancer Res 1988; 48: 4770-5.

36 Bishop PR, Awad J, DuBois RN. Inhibition of immediate early gene expression by sulindac sulfide in rat intestinal epithelial cells. Gastroenterology 1994; 106: A 372.

37 DuBois RN, Awad J, Morrow J, Roberts LJ, Bishop PR Regulation of eicosanoid production and mitogenesis in rat intestinal epithelial cells by transforming orowth factor-alpha and phorbol ester. 7 Clin Invest 1994; 93: 493-8. 
38 Shiff SJ, Tsai L, Qiao L, Rigas B. The effect of sulindac on cell proliferation and the cell cycle distribution of human colon cancer cells. Gastroenterology 1994; 106: A440.

39 Verma AK, Ashendel CL, Boutwell RK. Inhibition by prostaglandin synthesis inhibitors of the induction of epidermal ornithine decarboxylase activity, the accumulation of prostaglandins, and tumor promotion caused by 12-O-tetradecanoylphorbol-13-acetate. Cancer Res 1980; 40: 308-15.

40 Pasricha PJ, Bedi A, Rashid A, Hamilton SR, Akhtar AJ, O'Connor $\mathrm{K}$, et al. Inhibition of apoptosis in familial $\mathrm{O}$ 'Connor $\mathrm{K}$, et al. Inhibition of apoptosis in familial adenomatous polyposis (FAP) and its modification by sulindac. Gastroenterology 1995; 108: A523.

41 Shiff SJ, Qiao L, Tsai L, Rigas B. Sulindac and sulindac sulfide reduce the level and activity of cyclin dependent kinases and induce apoptosis in HT-29 colon adenocarcinoma cells. Gastroenterology 1995; 108: A537.

42 Bodmer WF, Bailey CJ, Bodmer J, Bussey HJ, Ellis A Gorman P, et al. Localization of the gene for familial adenomatous polyposis on chromosome 5. Nature 1987; 328: 614-6.

$43 \mathrm{Su} \mathrm{LK}$, Johnson KA, Smith KJ, Hill DE, Vogelstein B, Kinzler KW. Association between wild type and mutant APC gene products. Cancer Res 1993; 53: 2728-31.

44 Smith KJ, Johnson KA, Bryan TM, Hill DE, Markowitz S, Willson JK, et al. The APC gene product in normal and Willson JK, et al. The APC gene product in normal and
tumor cells. Proc Natl Acad Sci USA 1993; 90: 2846-50. 45 Lim S, Sigmund CD, Gross KW, Maquat L. Nonsense codons in human $\beta$-globin mRNA result in the produc-
cons tion of mRNA degradation products. Mol Cell Biol 1992; 12: 1149-61. 